\title{
Petrology of the Nishidohira Cortlandtitic Mass in the Southern Abukuma Mountains, Northeast Japan
}

\author{
Hisao Tanaka \\ Department of Earth Sciences, Yamagata University, Yamagata 990, Japan. \\ SATOSHI KanISAWA \\ Department of Earth Sciences, College of General Education, \\ Tohoku University, Sendai 980, Japan. \\ HITOSHI ONUKI \\ Department of Earth Sciences, Hirosaki University, Hirosaki 036, Japan.
}

\begin{abstract}
The Nishidohira cortlandtitic mass of probable Late Mesozoic age in the southern Abukuma Mountains has been characterized on the basis of field evidence, microscopic observations and chemical analyses of rocks and minerals. Though the mass is small, it is composed of various rock types.

Cortlandtite, quartz hornblende gabbro, monzonite and syenite are products of clinopyroxene dominated fractionation of a picrite-basaltic magma. Whereas amphibole-dominated fractionation played an important role in the formation of hornblende gabbro, quartz diorite and granite from a fairly $\mathrm{MgO}$-poor basaltic magma. The two rock groups are probably not comagmatic, but might have originated from a common parental material enriched in $K$ and $\mathrm{Rb}$ and depleted in $\mathrm{Ni}$. The two effective fractionations had occurred before the intrusion to the present position.

The cortlandtite has crystallized under conditions of $7-9 \mathrm{~kb}>P_{\text {total }}>5 \pm 2 \mathrm{~kb}, P_{\mathrm{H}_{2} \mathrm{O}} \geq 2-3$ $\mathrm{kb}$, and had equilibrated at temperatures from 1000 to less than $750^{\circ} \mathrm{C}$. Prevailing high $\mathrm{P}_{\mathrm{H}_{2} \mathrm{O}}$ and slow cooling of the mass brought about considerably low equilibration temperatures. When the almost congealed cortlandtite had intruded at about $5 \pm 2 \mathrm{~kb}$, the latest liquid of the clinopyroxene-dominated fractionation was segregated to form the syenite and monzonite.
\end{abstract}

\section{Introduction}

A peridotite composed of large amphibole crystals with poikilitically included olivine crystals is called "Cortlandtite". The name was adopted first to a hornblende peridotite of the Cortlandt complex, New York by Williams (1886).

A small cortlandtitic mass consisting of cortlandtite, hornblende* gabbro, quartz diorite and syenite etc. occurs in Nishidohira of the southern Abukuma Mountains, Northeast Japan (Watanabe, 1921). Since the Nishidohira cortlandtitic mass is composed of many rock types, it seems to be a good subject to unrabel the genesis of cortlandtite. It is the goal of this paper to characterize the cortlandtitic mass and discuss its genesis.

\section{Field relationship and intrusion age}

The southern Abukuma Mountains is

* "Hornblende" in this usage is synonymors with Ca-amphibole.

(Manuscript received September 13, 1982) 


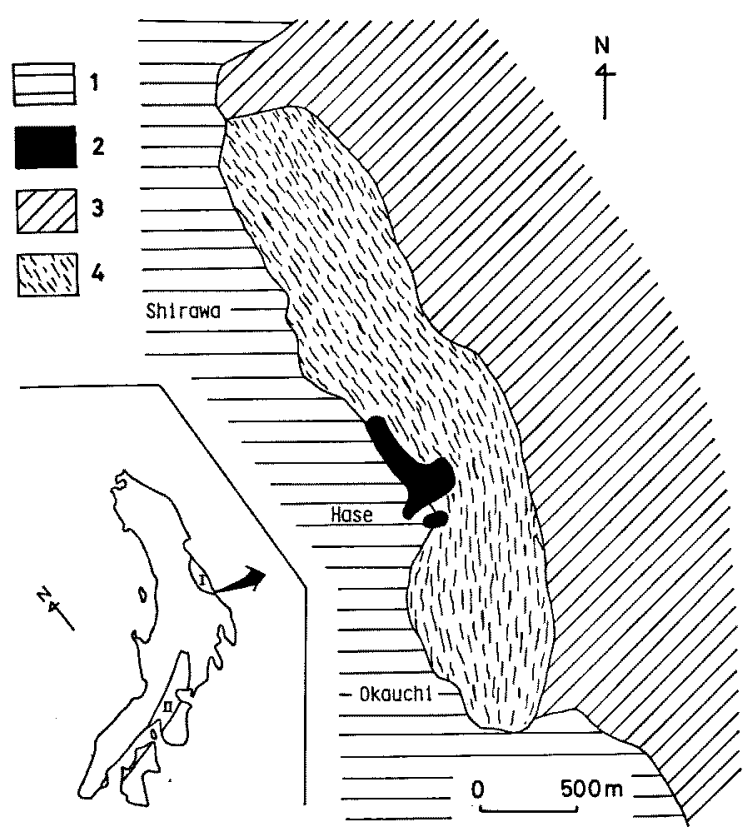

Fig. 1. Generalized geological map of the Nishidohira district. After Shimaoka and Watanabe (1976), partly modified by the authors.

Legend 1: Neogene sediments, 2: The Nishidohira cortlandtitic mass, 3: The Hitachi metamorphic rocks, 4: The Nishidohira metamorphic rocks, I: The Abukuma Mountains, II: The Ryoke metamorphic terrane.

underlain chiefly by the Hitachi metamorphic rocks and the Nishidohira metamorphic rocks* (Fig. 1). The Nishidohira cortlandtitic mass intruded into the Nishidohira metamorphic rocks which consist mainly of mica gneiss, mica schist and amphibolite of the amphibolite facies. Common mineral assemblages of the Nishidohira metamorphic rocks are hornblende+andesine in basic rocks and biotite+muscovite + sillimanite + plagioclase in pelitic rocks (Tagiri, 1973).

The cortlandtitic mass is separated into a main body and a small ovidal body (Fig.1).
Route maps across the eastern part of the main body and along a gorge in the small body are shown in Figs. $2 \mathrm{a}$ and $2 \mathrm{~b}$. The main body is in contact with the metamorphic rocks on the north and east, and is overlain by the Neogene sediments on the south (Fig. 2a). The main body tilts to the north-east side and the upper contact of the main body with the metamorphic rocks is observed.

As shown in the route maps, a major part of the mass is occupied by cortlandtite. As a whole, olivine-bearing cortlandtite occupies the south-west side, that is to say, the lower part of the main body. Several xenoliths of metamorphic rocks which have essentially similar mineral assemblages to those of the surrounding metamorphic rocks, several $\mathrm{cm}$ to $10 \mathrm{~m}$ in length, and a few blocks of clinopyroxenite, up to $30 \mathrm{~cm}$ in length, are included in the cortlandtites. Cortlandtites are cut by some fine- to medium-grained dikes of quartz hornblende gabbro, hornblende gabbro and quartz diorite, measuring from several $\mathrm{cm}$ to $10 \mathrm{~m}$ in width. The quartz diorite also occurs in less abundance as patches, up to $50 \mathrm{~cm}$ in length, in the cortlandtite. Throughout the cortlandtites, there are many leucocratic cross cutting veins and patches, consisting of syenite and monzonite. The veins have thickness of a few $\mathrm{mm}$ up to $1 \mathrm{~m}$. The patches, ranging from several $\mathrm{cm}$ to $1 \mathrm{~m}$ in length, are ovoidal and lenticular in shape. Granite veins up to $20 \mathrm{~cm}$ in width rarely intrude into the cortlandtite, hornblende gabbro and neighboring gneiss. Contact metamorphism is not conspicuous around the cortlandtitic mass.

A K-Ar biotite dating was carried out,

* "The Nishidohira metamorphic rocks" used in this paper corresponds to the Nishidohira Formation of the Hitachi metamorphic rocks (Tagiri, 1971, 1973), and the Nishidohira metamorphic complex (Shimaoka and Watanabe, 1976). 


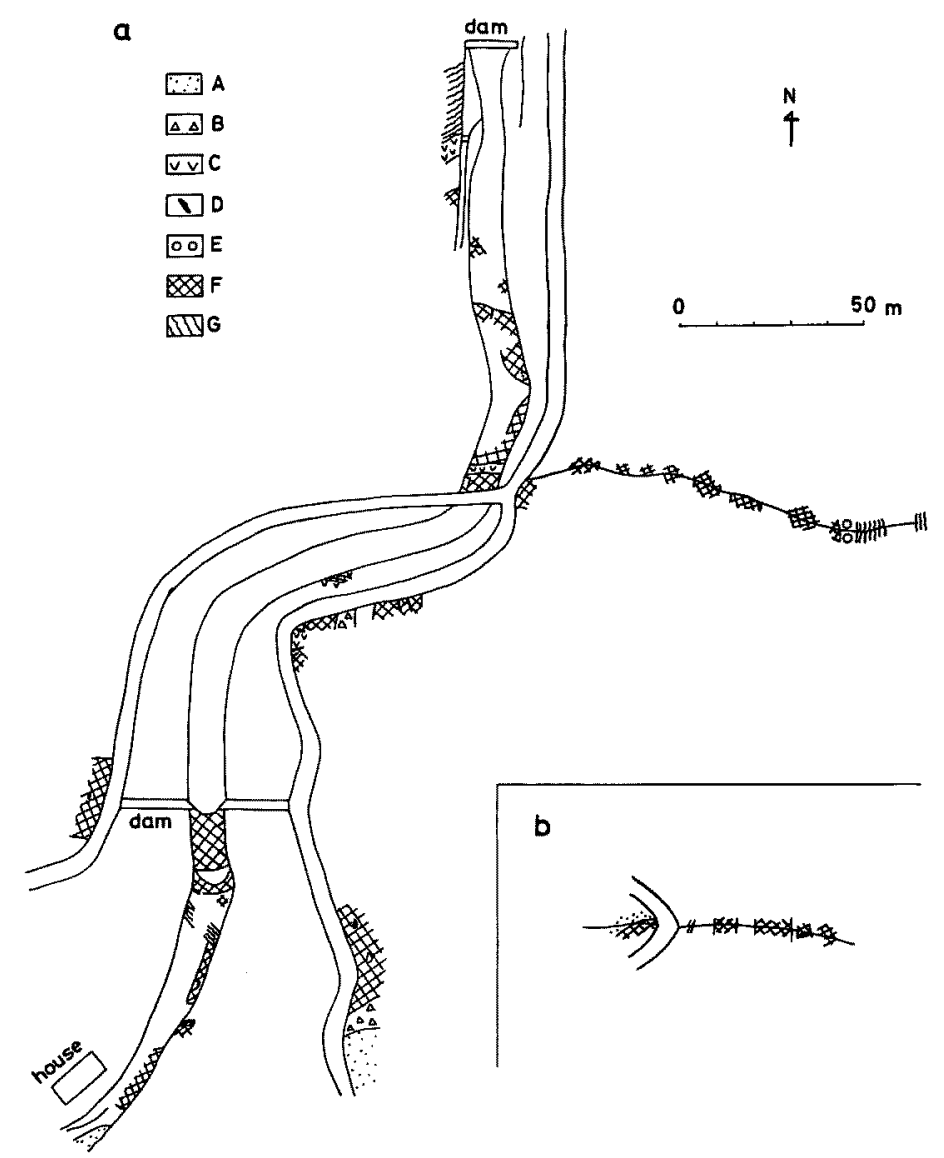

Figs. 2a and 2b. Route maps of the Nishidohira cortlandtitic mass.

Legend A: Neogene sedimens, B: Quartz diorite, C: Hornblende gabbro, D, Syenite and Monzonite, E: Quartz hornblende gabbro, F: Cortlandtite, G: Metamorphics.

and quartz diorite dike cutting the cortlandtite was now dated as $83 \mathrm{Ma}$. The age thus obtained is slightly younger than $\mathrm{K}$-Ar ages of neighboring metamorphic and granitic rocks, ranging from 120 to $90 \mathrm{Ma}$ (Kawano and Ueda, 1965; Shibata, 1968; Ueda et al., 1969a; Watanabe and Bikerman, 1971).

\section{Petrography}

\section{Cortlandtite}

Although some Nishidohira ultramafic rocks contain poikilitic Ca-amphibole, they are not cortlandtite in the strict sense because of their complete lack of olivine. However, both olivine-bearing and olivinefree poikilitic Ca-amphibole-rich rocks are called collectively cortlandtite in this paper, because both rocks exhibit similar appearance and microscopic texture.

The cortlandtite consists essentially of clinopyroxene and poikilitic brown $\mathrm{Ca}$ amphibole in varying proportions, with lesser amounts of olivine, orthopyroxene, phlogopite, plagioclase, apatite and opaque minerals. Both olivine and orthopyroxene form up to $5 \%$ of the mode. Secondary minerals, such as carbonate, serpentine, chlorite and sericite etc. are contained but 
are trivial in volume.

Olivine, up to $3 \mathrm{~mm}$ in diameter, is often replaced by serpentine, opaque minerals or carbonate to varying degrees. Subhedral orthopyroxene, up to $2 \mathrm{~mm}$ long, rarely emblaces olivine and is sometimes replaced by colorless Ca-amphibole at the margin. Subhedral large clinopyroxene, up to $4 \mathrm{~mm}$ in length, rarely contain olivine ophitically. Clinopyroxene is frequently replaced by Ca-amphibole to some extent, and many small clinopyroxenes show fairly irregular outlines. Greenish brown to brown Ca-amphiboles, up to 10 $\mathrm{mm}$ in length, poikilitically enclose olivine, orthopyroxene, clinopyroxene and opaque minerals. The Ca-amphiboles are partly stained with fine exsolved minerals (probably ilmenites) arranged along the cleavages. Pale green to colorless Ca-amphiboles occur in a minor amount, surrounding the brown Ca-amphiboles or filling the interstices between the large brown Ca-amphiboles. The pale green to colorless $\mathrm{Ca}$-amphiboles sometimes form a fine-grained mosaic aggregate. Phlogopite occurs as a reaction product of other mafic silicates with a residual liquid. Interstitial plagioclase filling the interstices between Ca-amphiboles is commonly sericitized intensely.

Clinopyroxenite exhibits similar petrographic features to the cortlandtite, except for its fine grain size and abundance in clinopyroxene.

\section{Quartz hornblende gabbro}

The quartz hornblende gabbro is mainly composed of pale green to greenish brown Ca-amphibole, plagioclase and interstitial quartz, with small amounts of biotite, potash feldspar, sphene, apatite and opaque minerals.

\section{Hormblende gabbro}

The hornblende gabbro consists mainly of Ca-amphibole and plagioclase, with minor amounts of biotite, sphene, apatite, opaque minerals and rarely clinopyroxene. Euhedral to subhedral $\mathrm{Ca}$-amphiboles are greenish brown or grassy green in Z-axial color. Subhedral to anhedral plagioclases sometimes contain minute Ca-amphibole inclusions.

\section{Quartz diorite}

The quartz diorite usually consists of brownish green Ca-amphibole, biotite, plagioclase and interstitial quartz, with accessory sphene, apatite and opaque minerals. Clinopyroxene, potash feldspar and garnet are rarely detected.

\section{Granite}

The granite contains scattered garnets up to $1.5 \mathrm{~mm}$ in diameter, and sometimes has a minor amount of muscovite, up to 3 $\mathrm{mm}$ in length.

\section{Syenite and monzonite}

The syenite and monzonite appear to have suffered deuteric alteration to varying degrees. As primary minerals, potash feldspar and plagioclase in varying proportions are essential constituents, and sphene, apatite, allanite and opaque minerals are common accessory constituents. Quartz and biotite are generally lack or rare. Fairly large crystals of chlorite, epidote, muscovite and carbonate, all of which are typically anhedral and could be products of deuteric alteration, are sometimes found but subordinate in amount. Potash feldspar undergoes kaolinitization in varying degrees. Plagioclase is almost wholly replaced by albite, by albite and sericite, or by albite and epidote. 


\section{Whole rock chemistry}

Results of chemical analyses of $\mathbf{3 1}$ representative rock samples are given in Table 1, together with C.I.P.W. norms. Major elements were determined by the conventional wet method. $\mathrm{Na}_{2} \mathrm{O}$ and $\mathrm{K}_{2} \mathrm{O}$ were determined by flame photometry. Atomic absorption spectrometry was used for the analyses of $\mathrm{MgO}(<1$ wt. \%), $\mathrm{CaO}$ $(<1$ wt. \%), $\mathrm{Rb}, \mathrm{Sr}, \mathrm{Ni}, \mathrm{Co}$ and $\mathrm{Cr}$ following the methods of Ueda et al. (1969b), Terashima (1971), Koma and Kurasawa (1978) with a slight modification whenever necessary.
$F$ was determined using a selective ionelectrode after the same procedures as those described by Kanisawa (1979).

The cortlandtites are characterized by low $\mathrm{Al}_{2} \mathrm{O}_{3}$, high $\mathrm{MgO}$ and $\mathrm{CaO}$ contents, and high $\mathrm{K}_{2} \mathrm{O} / \mathrm{Na}_{2} \mathrm{O}$ ratios. They show a considerable variations in $\mathrm{SiO}_{2}, \mathrm{Al}_{2} \mathrm{O}_{3}, \mathrm{MgO}$ and $\mathrm{CaO}$ reflecting variable amounts of clinopyroxene and $\mathrm{Ca}$-amphibole. Olivinebearing cortlandtites have higher Solidification Index (SI) of Kuno et al. (1957) than olivine-free cortlandtites. As regard to minor elements, cortlandtites are depleted in $\mathrm{Ni}$, $\mathrm{Co}$ and $\mathrm{Cr}$, and enriched in

Table 1. Chemical compositions of rocks of the Nishidohira cortlandtitic mass

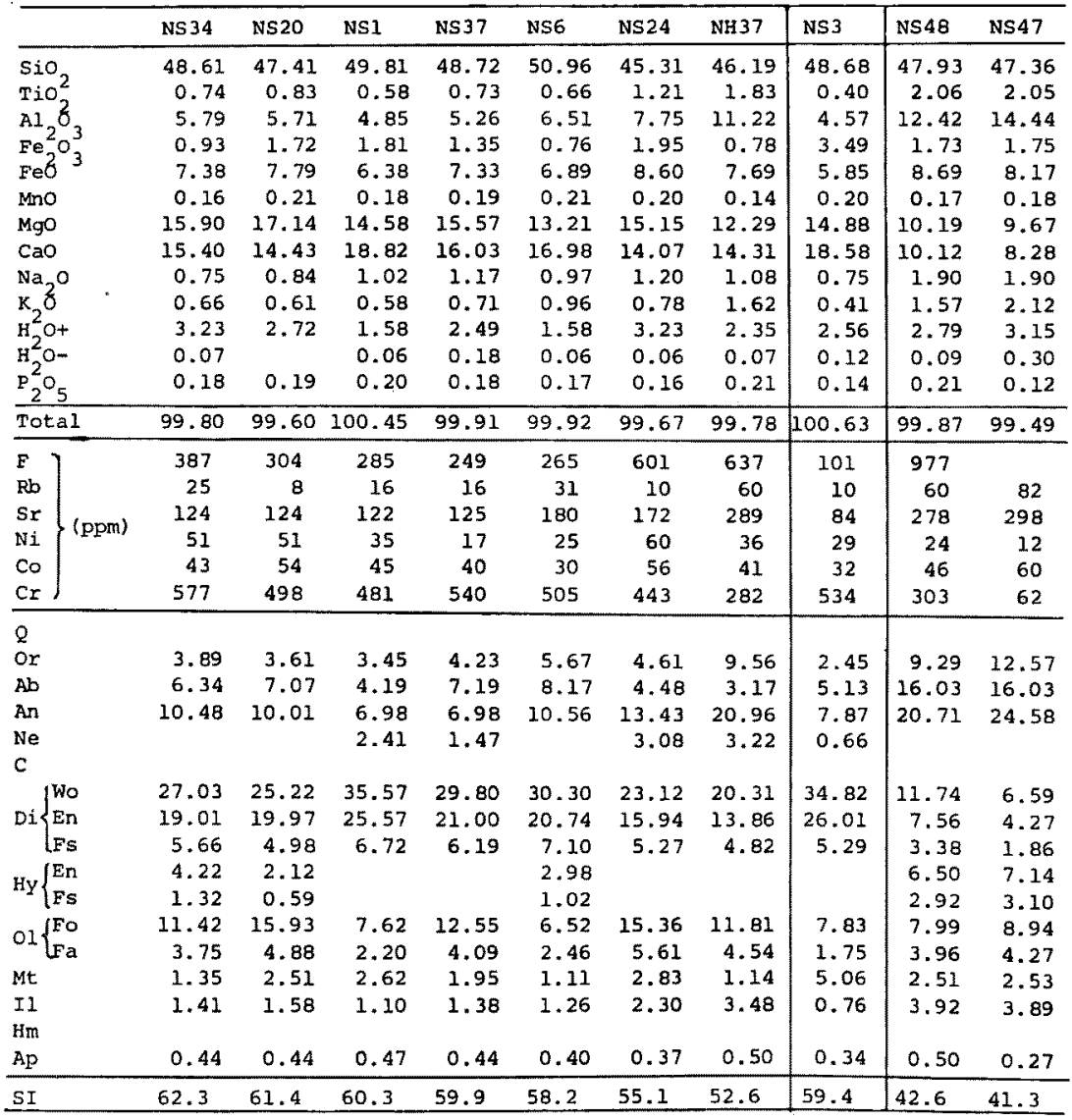

NS34-NS37: Olivine-bearing cortlandtite, NS6-NH37: Olivine-free crotalndtite, NS3: Clinopyroxenite, NS48 and NS47: Quartz hornblende gabbro. 
Table 1. (continued)

\begin{tabular}{|c|c|c|c|c|c|c|c|c|c|c|c|}
\hline & NSI7 & NS45 & NS 18 & NS 12 & NS68 & NSII & NS9 & NS7 & NS 14 & N529 & NS 19 \\
\hline $\mathrm{SiO}_{2}$ & 46.36 & 46.65 & 43.04 & 43.77 & 45.78 & 44.77 & 51.03 & 54.22 & 54.43 & 63.28 & 70.85 \\
\hline $\mathrm{TiO}_{2}^{2}$ & 1.36 & 1.47 & 1.65 & 1.64 & 1.72 & 1.30 & 1.13 & 1.26 & 0.76 & 0.42 & 0.15 \\
\hline $\mathrm{Al}_{2} \mathrm{O}_{3}$ & 14.04 & 13.48 & 15.11 & 18.11 & 19.01 & 21.01 & 18.96 & 20.42 & 21.34 & 18.14 & 15.98 \\
\hline & 1.89 & 2.55 & 2.44 & 3.06 & 1.70 & 2.30 & 1.37 & 0.52 & 1.44 & 0.52 & 0.22 \\
\hline Feo & 9.62 & 8.48 & 10.32 & 7.56 & 8.31 & 7.30 & 6.39 & 5.41 & 3.40 & 2.88 & 0.67 \\
\hline Mno & 0.20 & 0.22 & 0.28 & 0.20 & 0.19 & 0.15 & 0.16 & 0.11 & 0.07 & 0.04 & 0.39 \\
\hline Mgo & 8.63 & 8.56 & 8.61 & 7.21 & 4.98 & 4.26 & 4.93 & 3.43 & 2.89 & 2.20 & 0.08 \\
\hline $\mathrm{CaO}$ & 11.37 & 11.19 & 12.34 & 10.94 & 10.02 & 12.13 & 8.27 & 7.78 & 5.97 & 4.75 & 1.51 \\
\hline $\mathrm{Na}_{2} \mathrm{O}$ & 2.26 & 2.33 & 2.12 & 2.28 & 3.08 & 2.96 & 2.68 & 3.38 & 4.12 & 3.93 & 3.77 \\
\hline $\mathrm{K}_{2} \mathrm{O}$ & 1.09 & 1.55 & 1.34 & 2.02 & 1.87 & 1.05 & 2.26 & 1.57 & 2.50 & 1.85 & 5.65 \\
\hline $\mathrm{H}_{2}^{2} \mathrm{O}+$ & 2.41 & 2.40 & 2.34 & 2.59 & 2.17 & 1.99 & 2.18 & 1.74 & 2.58 & 1.25 & 0.22 \\
\hline $\mathrm{H}_{2}^{2} \mathrm{O}-$ & 0.10 & 0.04 & 0.05 & 0.10 & 0.07 & 0.27 & 0.32 & 0.17 & 0.13 & 0.06 & 0.05 \\
\hline${ }^{2} O_{5}$ & 0.40 & 0.55 & 0.43 & 0.74 & 0.76 & 0.77 & 0.64 & 0.43 & 0.49 & 0.35 & 0.16 \\
\hline Total & 99.73 & 99.47 & 100.07 & 100.22 & 99.66 & 100.26 & 100.32 & 100.44 & 100.12 & 99.77 & 99.70 \\
\hline $\mathbf{F}$ & 1180 & 829 & 1301 & 1090 & 847 & 723 & 724 & 436 & 322 & 198 & 155 \\
\hline $\mathrm{Fb}$ & 17 & 43 & 14 & 40 & 42 & 19 & 60 & 52 & 67 & 96 & 149 \\
\hline$S x$ & 481 & 597 & 460 & 593 & 839 & 945 & 535 & 613 & 737 & 621 & 1.71 \\
\hline $\mathrm{Ni}$ & 33 & 20 & 16 & 16 & 3 & 7 & 18 & 13 & 24 & 23 & tr \\
\hline Co & 48 & 49 & 50 & 58 & 39 & 34 & 43 & 36 & 48 & 40 & 12 \\
\hline $\mathrm{Cr}$ & 267 & 157 & 134 & 82 & 12 & 3 & 60 & 29 & 30 & 27 & tr \\
\hline$Q$ & & & & & & & 0.25 & 4.55 & 3.41 & 19.04 & 23.72 \\
\hline or & 6.45 & 9.17 & 7.95 & 11.95 & 11.06 & 6.23 & 13.34 & 9.29 & 14.79 & 10.95 & 33.42 \\
\hline$A b$ & 17.44 & 17.46 & 4.45 & 9.94 & 18.24 & 16.05 & 22.64 & 28.56 & 34.85 & 33.22 & 31.86 \\
\hline An & 24.88 & 21.71 & 27.69 & 33.14 & 32.47 & 40.89 & 33.00 & 35.83 & 26.38 & 21.27 & 6.48 \\
\hline $\mathrm{Ne}$ & 0.92 & 1.22 & 7.30 & 5.06 & 4.23 & 4.85 & & & & & \\
\hline$c$ & & & & & & & & 0.01 & 2.16 & 1.86 & 1.28 \\
\hline Wo & 12.09 & 12.61 & 12.85 & 6.83 & 5.12 & 5.97 & 1.62 & & & & \\
\hline$D i\{E n$ & 6.95 & 7.74 & 7.30 & 4.27 & 2.61 & 3.06 & 0.90 & & & & \\
\hline Fs & 4.58 & 4.13 & 4.99 & 2.14 & 2.38 & 2.76 & 0.66 & & & & \\
\hline $\mathrm{Hy}\left\{\left\{^{\mathrm{En}}\right.\right.$ & & & & & & & 11.43 & 8.58 & 7.23 & 5.50 & 0.20 \\
\hline "IFs & & & & & & & 8.37 & 7.52 & 3.92 & 4.22 & 1.52 \\
\hline Fo & 10.24 & 9.56 & 9.96 & 9.63 & 6.89 & 5.31 & & & & & \\
\hline${ }^{1}\{F a$ & 7.44 & 5.64 & 7.50 & 5.30 & 6.94 & 5.29 & & & & & \\
\hline Mt & 2.74 & 3.69 & 3.55 & 4.43 & 2.46 & 3.34 & 2.00 & 0.77 & 2.09 & 0.77 & 0.32 \\
\hline Il & 2.58 & 2.80 & 3.13 & 3.12 & 3.27 & 2.48 & 2.14 & 2.40 & 1.44 & 0.81 & 0.29 \\
\hline \multicolumn{12}{|l|}{$\mathrm{Hm}$} \\
\hline Ap & 0.94 & 1.31 & 1.01 & 1.75 & 1.81 & 1.81 & 1.51 & 1.01 & 1.88 & 0.84 & 0.37 \\
\hline SI & 37.0 & 36.9 & 35.0 & 33.0 & 25.2 & 24.1 & 28.2 & 24.1 & 20.3 & 19.4 & 0.8 \\
\hline
\end{tabular}

NS17-NS11: Hornblende gabbro, NS9-NS29: Quarzzdiorite, NS19: Granite.

$\mathrm{Rb}$ and $\mathrm{Sr}$, in comparison with the average values given by Goles (1967) for ultramafic rocks. A clinopyroxenite is positively comparable with the olivine-bearing cortlandtites in chemistry.

The quartz hornblende gabbros are enriched in $\mathrm{K}_{2} \mathrm{O}$ and $\mathrm{Rb}$, which are comparable to those of alkali basalts (Prinz, 1967; Hart et al., 1970), and are poor in Ni. The quartz hornblende gabbros are rich in $\mathrm{MgO}$ as compared with the hornblende gabbros, though they contain a considerable amount of modal quartz.

The hornblende gabbros are poor in $\mathrm{SiO}_{2}$ and are alkaline in terms of the silica-alkali diagram of Irvine and Baragar (1971) (Fig.3). They are fairly rich in $\mathrm{K}_{2} \mathrm{O}, \mathrm{F}, \mathrm{Rb}$ and

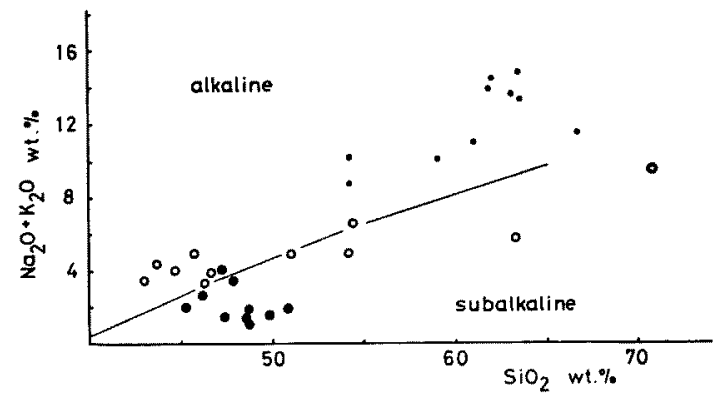

Fig. 3. $\mathrm{SiO}_{2}-\left(\mathrm{Na}_{2} \mathrm{O}+\mathrm{K}_{2} \mathrm{O}\right)$ diagram of rocks. Solid circles represent analyses of cortlandtite and quartz hornblende gabbro, open circles indicate those of hornblende gabbro, quartz diorite and granite, and small dots include those of syenite and monzonite. The solid curve is the line separating alkaline and subalkaline rocks chosen by Irvine and Baragar (1971).

$\mathrm{Sr}$, and poor in $\mathrm{Ni}$. All the hornblende gabbros are diopside-normative, and are 
Table 1. (continued)

\begin{tabular}{|c|c|c|c|c|c|c|c|c|c|c|}
\hline & NS33 & NS2 & NS1.3 & NS 36 & NS10 & NS 23 & NS 49 & NS 56 & NS63 & NS55 \\
\hline $\mathrm{SiO}_{2}$ & 54.27 & 59.12 & 54.35 & 63.63 & 61.87 & 63.13 & 63.55 & 66.77 & 61.09 & 62.06 \\
\hline $\mathrm{TiO}^{2}$ & 0.81 & 0.43 & 0.59 & 0.33 & 0.15 & 0.14 & 0.06 & 0.17 & 0.04 & 0.16 \\
\hline $\mathrm{Al}_{2} \mathrm{O}_{3}$ & 19.62 & 21.77 & 22.24 & 19.66 & 20.70 & 20.33 & 19.93 & 19.35 & 21.75 & 20.54 \\
\hline $\mathrm{Fe}_{2}^{2} \mathrm{O}_{3}^{3}$ & 1.48 & 0.45 & 1.15 & 0.19 & 0.26 & 0.35 & 0.11 & 0.32 & 0.34 & 0.21 \\
\hline $\mathrm{FeO}$ & 2.20 & 1.89 & 2.52 & 0.57 & 0.25 & 0.33 & 0.26 & 0.18 & 0.18 & 0.19 \\
\hline MnO & 0.06 & 0.03 & 0.06 & 0.02 & 0.01 & 0.02 & 0.01 & 0.02 & 0.01 & 0.01 \\
\hline Mgo & 2.80 & 1.76 & 1.89 & 0.70 & 0.27 & 0.25 & 0.09 & 0.06 & 0.04 & 0.02 \\
\hline $\mathrm{CaO}$ & 5.51 & 1.86 & 4.84 & 0.45 & 1.40 & 0.40 & 0.60 & 0.42 & 3.33 & 1.32 \\
\hline $\mathrm{Na}_{2} \mathrm{O}$ & 6.10 & 8.40 & 4.36 & 7.69 & 3.23 & 5.10 & 3.11 & 7.53 & 9.02 & 3.18 \\
\hline $\mathrm{x}_{2} \mathrm{O}$ & 2.63 & 1.62 & 5.84 & 5.52 & 10.60 & 8.49 & 11.60 & 3.96 & 1.94 & 11.24 \\
\hline $\mathrm{H}_{2}^{2} \mathrm{O}+$ & 3.83 & 2.06 & 1.44 & 0.86 & 0.55 & 0.94 & 0.68 & 0.78 & 1.69 & 0.58 \\
\hline $\mathrm{H}_{2}^{2} \mathrm{O}-$ & 0.19 & 0.18 & 0.12 & 0.11 & 0.14 & 0.16 & 0.01 & 0.09 & 0.10 & 0.05 \\
\hline $\mathrm{P}_{2}^{2} \mathrm{O}_{5}$ & 0.28 & 0.19 & 0.33 & 0.15 & 0.20 & 0.12 & 0.12 & 0.14 & 0.25 & 0.17 \\
\hline Total & 99.78 & 99.76 & 99.73 & 99.88 & 99.63 & 99.76 & 100.13 & 99.79 & 99.78 & 99.73 \\
\hline$F$ & 222 & 136 & 293 & 88 & 186 & 74 & $\ll 64$ & $<64$ & 98 & $<<67$ \\
\hline $\mathbf{R b}$ & 64 & 56 & 170 & 118 & 171 & 162 & 214 & 85 & 56 & 185 \\
\hline Sx & 297 & 359 & 659 & 56 & 450 & 231 & 356 & 295 & 455 & 333 \\
\hline $\mathrm{Ni}$ & 12 & 30 & 30 & 10 & 12 & 14 & 14 & 9 & 18 & 15 \\
\hline Co & 29 & 30 & 46 & 23 & 22 & 22 & 21 & 17 & 29 & 22 \\
\hline $\mathrm{Cr}$ & 15 & 18 & 34 & 3 & tr & 1 & $t x$ & tr & tr & $t x$ \\
\hline$Q$ & & & & & & 0.04 & & 7.28 & & \\
\hline or & 15.57 & 9.56 & 34.53 & 32.64 & 62.72 & 50.21 & 68.61 & 23.41 & 11.45 & 66.50 \\
\hline$A b$ & 42.99 & 68.39 & 26.32 & 57.84 & 27.01 & 43.14 & 26.22 & 63.67 & 65.76 & 22.88 \\
\hline An & 18.35 & 8.03 & 21.88 & 1.20 & 5.64 & 1.22 & 2.22 & 1.17 & 13.09 & 5.45 \\
\hline $\mathrm{Ne}$ & 4.65 & 1.42 & 5.70 & 3.87 & 0.16 & & 0.05 & & 5.68 & 2.17 \\
\hline C & & 3.24 & 0.70 & 0.58 & 1.82 & 2.27 & 1.41 & 2.23 & & 1.11 \\
\hline Wo & 2.98 & & & & & & & & 0.74 & \\
\hline Di $\{$ En & 2.19 & & & & & & & & 0.10 & \\
\hline lFs & 0.50 & & & & & & & & & \\
\hline Hy $\left\{\begin{array}{l}\text { En } \\
F S\end{array}\right.$ & & & & & & 0.63 & & 0.15 & & \\
\hline$\{F O$ & 3.37 & 3.31 & 3.08 & 1.23 & 0.48 & & 0.16 & & & 0.04 \\
\hline${ }^{O}\{\mathrm{Fa}$ & 0.84 & 2.16 & 1.89 & 0.30 & 0.01 & & 0.22 & & & \\
\hline Mt & 2.16 & 0.65 & 1.67 & 0.28 & 0.37 & 0.51 & 0.16 & 0.16 & 0.49 & 0.16 \\
\hline II & 1.54 & 1.12 & 0.82 & 0.62 & 0.29 & 0.27 & 0.12 & 0.32 & 0.08 & 0.30 \\
\hline $\mathrm{Hm}$ & & & & & & & & 0.21 & & 0.10 \\
\hline $\mathrm{Ap}$ & 0.67 & 0.44 & 0.77 & 0.37 & 0.47 & 0.27 & 0.27 & 0.34 & 0.60 & 0.40 \\
\hline$S I$ & 18.6 & 12.5 & 12.1 & 4.8 & 1.9 & 1.7 & 0.6 & 0.5 & 0.3 & 0.1 \\
\hline
\end{tabular}

NS33-NS55 (except NS13): Syenite, NS13: Monzonite.

apparently richer in $\mathrm{P}_{2} \mathrm{O}_{5}$ than the quartz hornblende gabbros.

The analysed quartz diorites and granite show a very wide variation in $\mathrm{SiO}_{2}$ from 51 to 71 wt.\%. They are fairly rich in $\mathrm{Al}_{2} \mathrm{O}_{3}$, and ormative corundum are counted in four out of five analysed samples.

The syenites and monzonite are characterized by moderate $\mathrm{SiO}_{2}$, high $\mathrm{Al}_{2} \mathrm{O}_{3}$, high $\mathrm{Na}_{2} \mathrm{O}$ and/or high $\mathrm{K}_{2} \mathrm{O}$. The syenites except for a carbonate-rich sample (NS33) are very poor in cafemic oxides. Their $\mathrm{Na}_{2} \mathrm{O}$ and $\mathrm{K}_{2} \mathrm{O}$ contents are variable in very wide ranges, i.e. $\mathrm{Na}_{2} \mathrm{O}$ from 3.1 to 9.0 wt.\%, and $\mathrm{K}_{2} \mathrm{O}$ from 1.6 to $11.6 \mathrm{wt}$. \%. The least altered rocks are very rich in $\mathrm{K}_{\mathbf{2}} \mathrm{O}$, whereas the intensely altered rocks show very high
$\mathrm{Na}_{2} \mathrm{O}$ contents.

\section{Mineral chemistry}

Mineral analyses were made with an electron-probe microanalyser (EPMA) of HITACHI model X-560S using an energydispersive X-ray analytical system. Correction procedures followed those described by Fujimaki and Aoki (1980)., Besides these EPMA analyses, some crystals of clinopyroxene, Ca-amphibole and biotite were separated and analysed in the same method as that of the whole rocks.

The Fo content of the olivines varies from 72 to 67, and the En content of the orthopyroxenes from 75 to 69 . Representative analyses of the olivines and ortho- 
pyroxenes are given in Table 2.

Clinopyroxenes in the cortlandtites are characterized by high $\mathrm{SiO}_{2}, \mathrm{MgO}$ and $\mathrm{CaO}$, and low $\mathrm{Al}_{2} \mathrm{O}_{3}, \mathrm{TiO}_{2}$ and $\mathrm{FeO}^{*}$ (all iron as $\mathrm{FeO}$ ). Representative analyses of the clinopyroxenes are given in Table 3 . Most of the clinopyroxenes are plotted in the diopside field close to the salite in the classification scheme of Poldervaart and Hess

Table 2. Chemical compositions of olivines and orthopyroxenes in cortlandtites

\begin{tabular}{lrr|rrr}
\hline & Olivine & \multicolumn{3}{c}{ Orthopyroxene } \\
& NS20 & NS1 & NS20 & NS1 & NS37 \\
\hline $\mathrm{SiO}_{2}$ & 37.48 & 37.18 & 53.87 & 53.64 & 54.05 \\
$\mathrm{TiO}_{2}$ & & & 0.20 & 0.10 & 0.07 \\
$\mathrm{Al}_{2} \mathrm{O}_{3}$ & & & 2.32 & 3.01 & 1.95 \\
$\mathrm{Cr}_{2} \mathrm{O}_{3}$ & & & 0.07 & & \\
$\mathrm{FeO}^{*}$ & 25.41 & 26.87 & 15.63 & 16.03 & 17.54 \\
$\mathrm{MnO}$ & 0.49 & 0.59 & 0.43 & 0.47 & 0.50 \\
$\mathrm{MgO}$ & 36.29 & 35.32 & 26.47 & 26.08 & 25.10 \\
$\mathrm{CaO}$ & 0.05 & & 0.96 & 0.53 & 0.45 \\
\hline Tota1 & 99.72 & 99.96 & 99.95 & 99.86 & 99.66 \\
\hline $\mathrm{Ca}$ atom & & & 1.9 & 1.1 & 0.9 \\
$\mathrm{Mg}$ & 71.4 & 69.6 & 73.4 & 73.0 & 70.6 \\
$\mathrm{Fe}$ & 28.6 & 30.4 & 24.7 & 25.9 & 28.5 \\
\hline
\end{tabular}

All analyses were done by EPMA.

Table 3. Chemical compositions of clinopyroxenes in cortlandtites

\begin{tabular}{lrrrrrr}
\hline & NS2Op & NS2Or & NS24p & NS24r & NH37 & NS3** \\
\hline $\mathrm{SiO}_{2}$ & 52.53 & 53.74 & 52.63 & 53.89 & 51.73 & 51.12 \\
$\mathrm{TiO}_{2}$ & 0.36 & 0.06 & 0.25 & 0.09 & 0.90 & 0.53 \\
$\mathrm{Al}_{2} \mathrm{O}_{3}$ & 2.91 & 0.75 & 2.78 & 0.82 & 2.47 & 2.98 \\
$\mathrm{Cr}_{2} \mathrm{O}_{3}$ & 0.29 & 0.11 & & & & 0.08 \\
$\mathrm{Fe}_{2} \mathrm{O}_{3}$ & & & & & 0.67 & 1.38 \\
$\mathrm{FeO}^{4}$ & 5.04 & 5.78 & 5.72 & 7.33 & 6.17 & 5.41 \\
$\mathrm{MnO}$ & 0.08 & 0.20 & 0.17 & 0.29 & 0.20 & 0.17 \\
$\mathrm{MgO}$ & 15.30 & 14.37 & 14.45 & 13.88 & 13.81 & 15.25 \\
$\mathrm{CaO}$ & 22.97 & 24.16 & 22.81 & 24.08 & 22.74 & 21.56 \\
$\mathrm{Na}$ & 0.61 & 0.85 & 0.98 & 0.39 & 0.52 & 0.62 \\
$\mathrm{~K}_{2} \mathrm{O}^{\circ}$ & & & & & 0.28 & 0.16 \\
\hline Total & 100.09 & 100.02 & 99.79 & 100.77 & 99.49 & 99.26 \\
\hline Ca atom & 47.6 & 49.5 & 48.0 & 48.8 & 47.9 & 44.7 \\
Mg & 44.1 & 40.9 & 42.3 & 39.1 & 40.7 & 44.3 \\
Fe & 8.3 & 9.6 & 9.7 & 12.1 & 11.4 & 11.0 \\
\hline
\end{tabular}

All analyses except NH37 and NS3 were done by EPMA. " $\mathrm{p}$ " represents primary clinopyroxene and " $r$ " indicates resorbed one. FeO" by EPMA analysis includes all iron as $\mathrm{FeO}$. **NS3 includes Ni $24 \mathrm{ppm}$ and Co $30 \mathrm{ppm}$.
(1951) (Fig. 4), and display a trend of slight iron enrichment accompaning decrease of $\mathrm{SI}$ in the whole rock. In the clinopyroxenes, as a whole, $\mathrm{Al}_{2} \mathrm{O}_{3}$ and $\mathrm{TiO}_{2}$ decrease with decreasing $\mathrm{Mg} /\left(\mathrm{Mg}+\mathrm{Fe}^{*}+\mathrm{Mn}\right.$ ) ratio (Fig. 5;

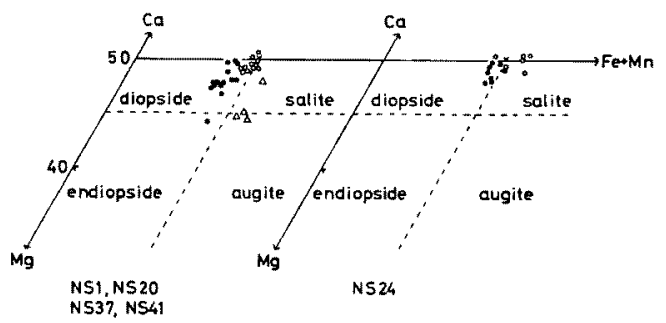

Fig. 4. Compositions of clinopyroxenes in cortlandtites.

Solid and open circles reprosent analyses (NS1, NS20, NS24, NS37, NS41) by EPMA, and triangles include those by wet method. Solid circles show primary clinopyroxenes and open circles indicate resorbed ones.. Two analyses from Onuki (1968) are used along with those reported in this paper.

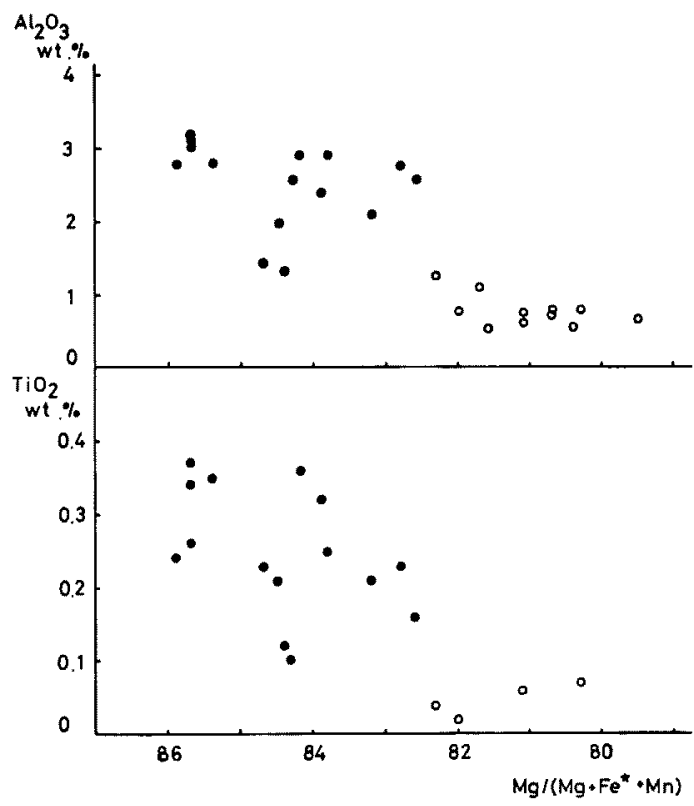

Fig. 5. Compositional variations of clinopyroxenes in cortlandtities.

Solid circles represent primary clinopyroxenes and open circles indicate resorbed ones. Some resorbed clinopyroxenes are too poor in $\mathrm{TiO}_{2}$ to analyse by EPMA. Clinopyroxene analyses from a rock of low SI (NS24) are excluded for simplification. 
$\mathrm{Fe}^{*}$ signifies total iron as $\left.\mathrm{Fe}^{2+}\right)$. Clinopyroxenes with $2-3$ wt. $\% \quad \mathrm{Al}_{2} \mathrm{O}_{3}$ and 0.1 0.4 wt. $\% \mathrm{TiO}_{2}$ are fairly large crystals and may represent primary phases, while $\mathrm{Al}_{2} \mathrm{O}_{3}-$ and $\mathrm{TiO}_{2}$-poor clinopyroxenes occurring as small ragged crystals are considered to be resorbed phases.

All the analysed Ca-amphiboles, except for pale green to colorless Ca-amphiboles in the cortlandtites and pale green Ca-amphibole in the quartz hornblende gabbro, are characterized by high $\mathrm{K}_{2} \mathrm{O}$ contents and high $\mathrm{K}_{2} \mathrm{O} / \mathrm{Na}_{2} \mathrm{O}$ ratios. All the Ca-amphiboles, except those from the hornblende gabbros, show a wide range of compositional variation even in a single crystal. Greenish brown to brown $\mathrm{Ca}$-amphiboles in the cortlandtites have pargasitic compositions rich in $\mathrm{Al}^{\mathrm{IV}}$ and $\mathrm{Na}+\mathrm{K}$, while pale green to colorless Ca-amphiboles show actinolitic compositions rich in $\mathrm{Si}$ and $\mathrm{Mg}$. Representative analyses of Ca-amphiboles are given in Table 4.

Phlogopites in the cortlandtites are usually low in $\mathrm{TiO}_{2}$ and high in $\mathrm{SiO}_{2}$ and $\mathrm{MgO}$. In all the biotites regular or substantial differences in major oxides except for $\mathrm{FeO}^{*}$ and $\mathrm{MgO}$ are not observed, and the $\mathrm{Mg} /\left(\mathrm{Mg}+\mathrm{Fe}^{*}\right)$ ratio ranges from 0.62 to 0.53 . Representative analyses of the

Table 5. Chemical compositions of phlogopites and biotites

\begin{tabular}{lrrrrr}
\hline & NS20 & \multicolumn{1}{c}{ NSI } & \multicolumn{1}{c}{ NS48 } & \multicolumn{1}{c}{ NS18 } & \multicolumn{1}{c}{ NS9 } \\
\hline $\mathrm{SiO}_{2}$ & 40.05 & 40.79 & 38.40 & 37.16 & 36.13 \\
$\mathrm{TiO}_{2}$ & 0.43 & 1.01 & 2.70 & 2.45 & 3.58 \\
$\mathrm{Al}_{2} \mathrm{O}_{3}$ & 15.95 & 14.31 & 15.43 & 15.90 & 16.26 \\
$\mathrm{Fe}_{2} \mathrm{O}_{3}$ & & & & & 0.98 \\
$\mathrm{FeOH}$ & 6.53 & 7.16 & 15.67 & 17.20 & 17.71 \\
$\mathrm{MnO}$ & & & 0.15 & 0.16 & 0.29 \\
$\mathrm{MgO}$ & 23.24 & 22.98 & 14.28 & 14.09 & 11.62 \\
$\mathrm{CaO}$ & 0.22 & 0.17 & 0.20 & 0.20 & 0.85 \\
$\mathrm{Na}$ & 0.89 & 0.87 & 0.26 & 0.49 & 0.40 \\
$\mathrm{~K}_{2} \mathrm{O}$ & 8.86 & 8.91 & 9.20 & 8.63 & 8.72 \\
$\mathrm{H}_{2} \mathrm{O}+$ & & & & & 3.74 \\
$\mathrm{H}_{2} \mathrm{O}$ & & & & & 0.09 \\
\hline $\mathrm{TOtal}$ & 96.17 & 96.20 & 96.29 & 96.28 & 100.37 \\
\hline $\mathrm{F}$ (Ppm) & & & & & 1520 \\
\hline $\mathrm{Mg} /\left(\mathrm{Mg}+\mathrm{Fe}^{*}\right)$ & 0.864 & 0.851 & 0.619 & 0.594 & 0.530 \\
\hline
\end{tabular}

All analyses except NS9 were done by EPMA. FeO by EPMA analysis includes all iron as FeO.

Table 4. Chemical compositions of Ca-amphiboles

\begin{tabular}{|c|c|c|c|c|c|c|c|c|c|c|c|}
\hline & $\mathrm{NS} 20 \mathrm{~b}$ & $\mathrm{NS} 20 \mathrm{C}$ & NSlb & NSIC & NS 24 & NH 37 & NS17 & NS1 8 & NSI 2 & NS 11 & NS9 \\
\hline $\mathrm{SiO}_{2}$ & 43.65 & 55.76 & 46.23 & 51.95 & 46.02 & 47.05 & 45.44 & 42.75 & 42.48 & 40.87 & 47.94 \\
\hline $\mathrm{TiO}_{2}$ & 2.02 & 0.04 & 1.19 & 0.67 & 1.21 & 1.00 & 1.10 & 1.15 & 1.16 & 1.17 & 0.91 \\
\hline $\mathrm{Al}_{2} \mathrm{O}_{3}$ & 12.43 & 2.07 & 10.70 & 5.53 & 9.21 & 9.01 & 10.16 & 11.48 & 12.42 & 12.61 & 7.47 \\
\hline $\mathrm{Fe}_{2} \mathrm{O}_{3}$ & 1.70 & 1.20 & 1.96 & 1.79 & 1.92 & 1.83 & 1.30 & 2.97 & 3.93 & 4.78 & 2.63 \\
\hline FeO & 7.48 & 5.25 & 8.60 & 7.85 & 9.38 & 9.99 & 13.11 & 32.54 & 11.00 & 13.96 & 13.02 \\
\hline Mno & 0.15 & 0.16 & 0.14 & 0.16 & 0.23 & 0.15 & 0.33 & 0.31 & 0.34 & 0.30 & 0.39 \\
\hline Mgo & 14.89 & 19.89 & 14.10 & 16.27 & 14.79 & 14.05 & 12.04 & 11.01 & 11.60 & 8.98 & 11.63 \\
\hline $\mathrm{CaO}$ & 12.61 & 12.51 & 12.62 & 12.66 & 12.36 & 12.43 & 12.07 & 12.12 & 12.09 & 11.97 & 11.91 \\
\hline $\mathrm{Na}_{2} \mathrm{O}$ & 1.78 & 0.47 & 1.23 & 0.83 & 1.45 & 1.30 & 1.07 & 1.67 & 1.65 & 1.74 & 0.99 \\
\hline $\mathrm{K}_{2} \mathrm{O}$ & 1.30 & 0.18 & 1.00 & 0.48 & 0.85 & 0.88 & 0.70 & 1.32 & 1.11 & 1.39 & 0.82 \\
\hline $\mathrm{H}_{2} \mathrm{O}+$ & & & & & 2.30 & 2.18 & 2.27 & 2.29 & 2.18 & 2.28 & 2.40 \\
\hline $\mathrm{H}_{2} \mathrm{O}-$ & & & & & 0.04 & 0.17 & 0.04 & 0.14 & 0.07 & 0.18 & 0.31 \\
\hline Total & 98.01 & 97.53 & 97.77 & 98.19 & 99.76 & 100.08 & 99.69 & 99.75 & 100.13 & 100.28 & 100.42 \\
\hline F & & & & & 653 & 713 & 1130 & 1210 & 1040 & 762 & 927 \\
\hline $\mathrm{Rb}$ & & & & & 6 & 9 & 3 & 4 & 4 & 4 & 4 \\
\hline $\mathrm{Ni}\}(\mathrm{ppm})$ & & & & & 42 & 44 & 20 & 18 & 11 & 14 & 6 \\
\hline Co & & & & & 48 & 53 & 41 & 68 & 36 & 31 & 34 \\
\hline $\mathrm{Cr}$ & & & & & 432 & 393 & 373 & 227 & 137 & 9 & 110 \\
\hline $\mathrm{Mg} /\left(\mathrm{Mg}+\mathrm{Fe}^{*}\right)$ & 0.746 & 0.848 & 0.708 & 0.754 & 0.706 & 0.685 & 0.603 & 0.560 & 0.590 & 0.469 & 0.576 \\
\hline
\end{tabular}

$\mathrm{Fe}_{2} \mathrm{O}_{3}$ contents of anhydrous analyses made with EPMA were calculated on the basis of $17 \%$ of total iron as $\mathrm{Fe}_{2} \mathrm{O}_{3}$; because the average $\mathrm{Fe}_{2} \mathrm{O}_{3} / \mathrm{FeO}^{*}$ ratio of seven $\mathrm{Ca}$-amphiboles analysed by wet method is 0.17 . " $b$ " represents brown Ca-amphibole and " $c$ " indicates colorless or pale green one. 
phlogopites and biotites are shown in Table 5 .

Plagioclases in the cortlandtite and quartz hornblende gabbro are fairly rich in $\mathrm{Na}_{2} \mathrm{O}$ and range in composition from $\mathrm{An}_{51}$ to $\mathrm{An}_{\mathbf{3 9}}$. Plagioclase from a hornblende gabbro (NS11) shows an abrupt decrease in An content from a homogeneous calcic core $\left(A n_{81-78}\right)$ to a sodic margin $\left(\mathrm{An}_{65-55}\right)$. Plagioclases from other hornblende gabbro

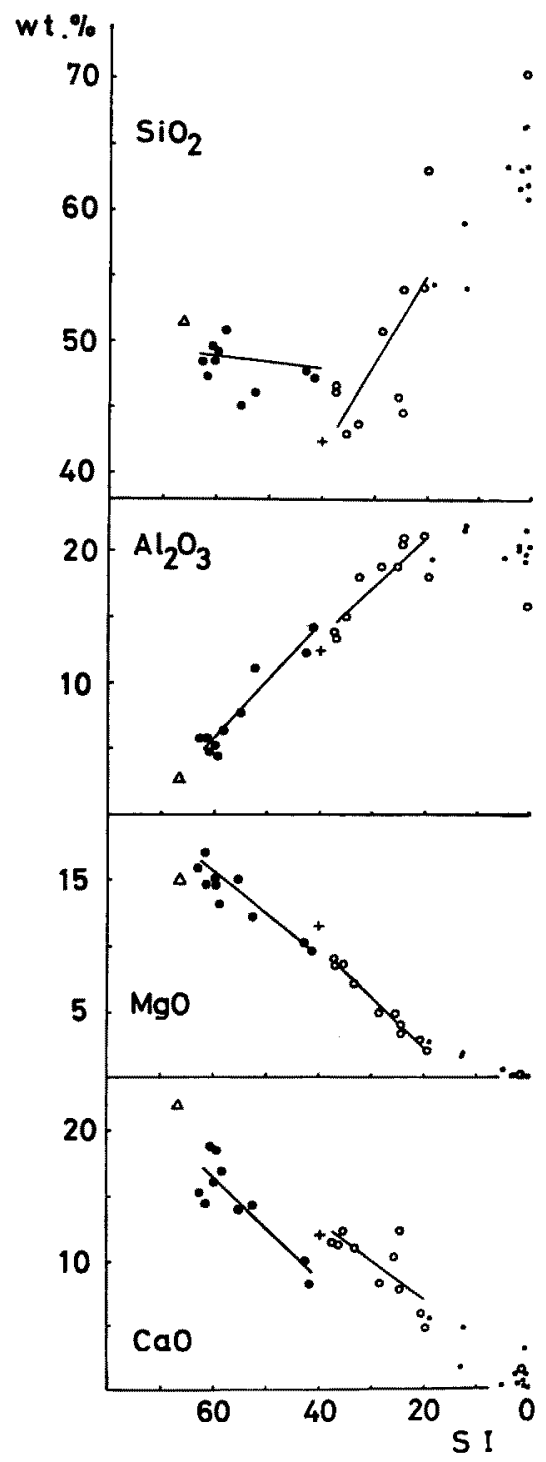

wt. $\%$

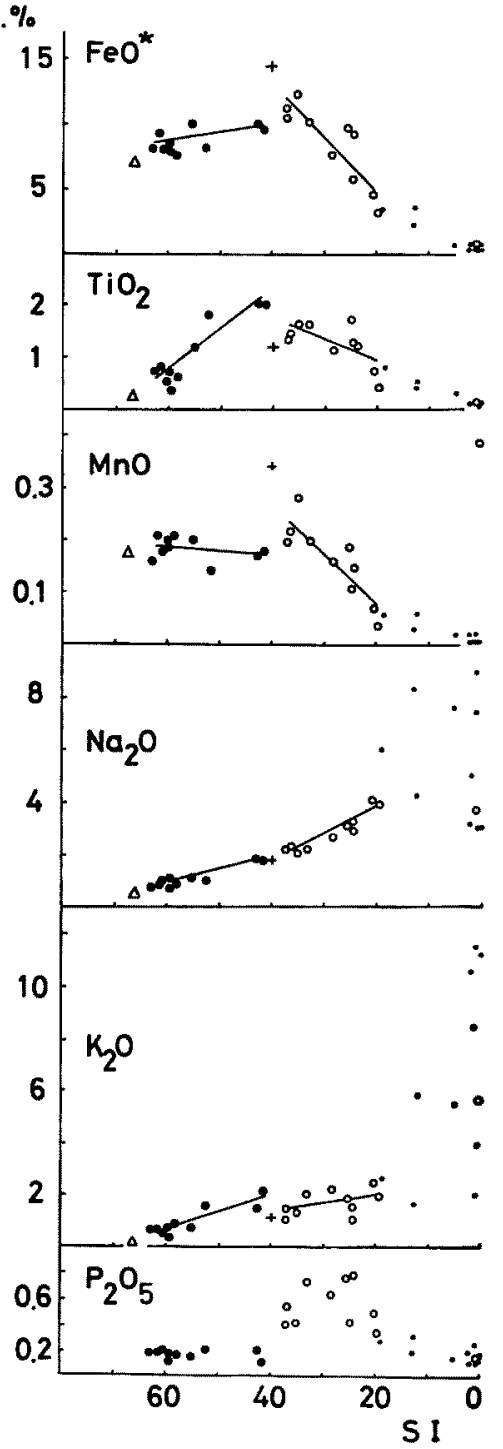

Figs. 6a. Variation of major elements with SI.

Solid circles represent analyses of cortlandtite and quartz hornblende gabbro, open circles indicate those of hornblende gabbro, quartz diorite and granite, and small dots include those of syenite and monzonite. Straight solid lines that represent variation trends of former two groups were calculated by the least squares method. Analysis of granite was excluded in the calculation. Open triangular represents analysis of NS3 clinopyroxene in clinopyroxenite, and cross indicates that the NS12 Ca-amphibole in hornblende gabbro. 

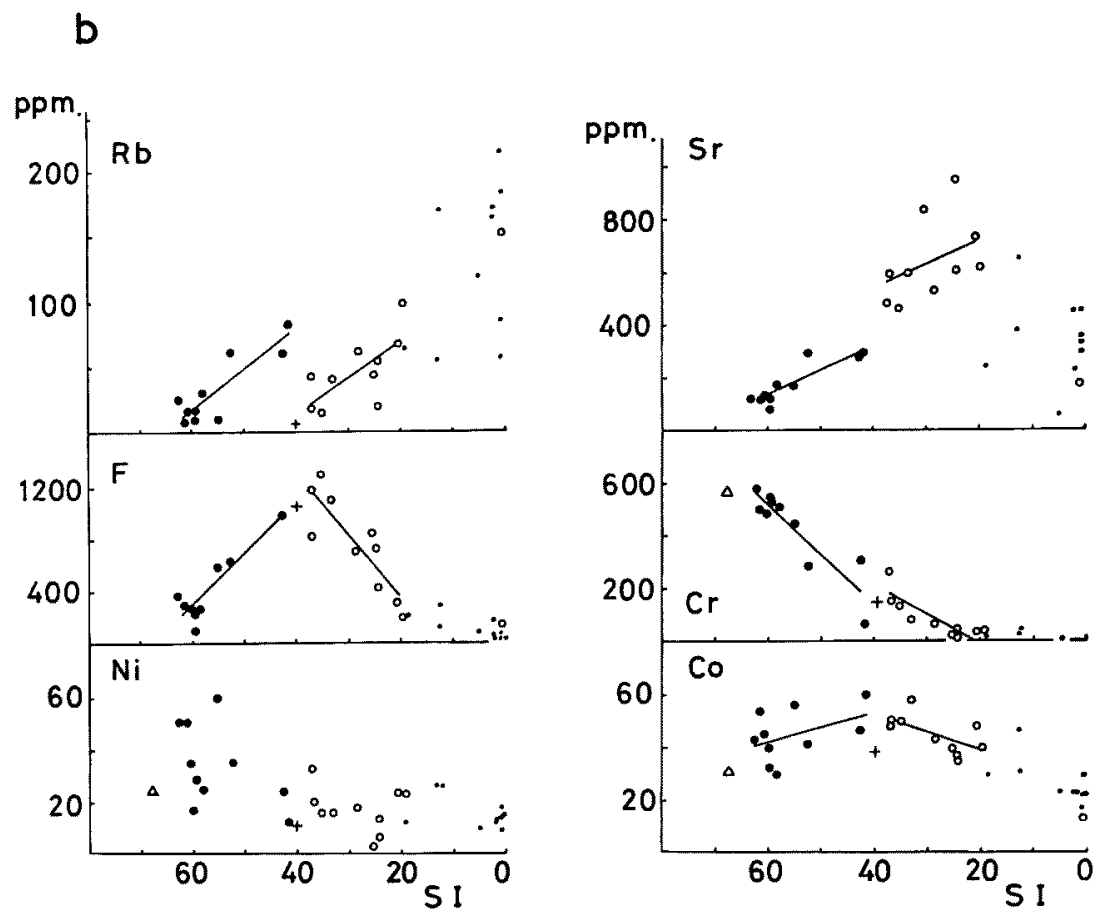

Fig. 6 b. Variasion of trace elements with SI.

and quartz diorite are fairly homogeneous and have a compositional range of $\mathrm{An}_{52}$ to $\mathrm{An}_{\mathbf{4 2}}$. Fresh potash feldspar in the syenite is rich in $\mathrm{K}_{2} \mathrm{O}$ and varies from $\mathrm{Or}_{\mathbf{8 2}}$ to $\mathrm{Or}_{80}$.

\section{Clinopyroxene-dominated fractionation and amphibole-dominated fractionation trends}

In Figs. 6a and 6b, major and trace elements, respectively, of the various rocks are plotted against SI. In the figures three groups are noticed. The first group consists of the cortlandtite and quartz hornblende gabbro, the second of the hornblende gabbro, quartz diorite and granite, and the last of the syenite and monzonite. The last group shows a large scatter in alkali metal elements $(\mathrm{Na}, \mathrm{K}, \mathrm{Rb})$, resulting from deuteric alteration.

The cortlandtite and quartz hornblende gabbro have SI over 40 , whereas the hornblende gabbro, quartz diorite and granite have SI under 40. In the former group, the contents of $\mathrm{MgO}, \mathrm{CaO}$ and $\mathrm{Cr}$ decrease steadily, and those of $\mathrm{TiO}_{2}, \mathrm{Al}_{2} \mathrm{O}_{3}, \mathrm{FeO}^{*}$, $\mathrm{Na}_{2} \mathrm{O}, \mathrm{K}_{2} \mathrm{O}, \mathrm{F}, \mathrm{Rb}$ and $\mathrm{Sr}$ increase almost linealy with decreasing SI. On the other hand, an almost linear decrease in $\mathrm{TiO}_{2}$, $\mathrm{FeO}^{*}, \mathrm{MgO}, \mathrm{MnO}, \mathrm{CaO}, \mathrm{F}$ and $\mathrm{Cr}$, and $\mathrm{a}$ steady increase in $\mathrm{SiO}_{2}, \mathrm{Al}_{2} \mathrm{O}_{3}, \mathrm{Na}_{2} \mathrm{O}$ and $\mathrm{Rb}$ with decreasing $\mathrm{SI}$ are recognized in the later group. The slopes of $\mathrm{SiO}_{2}, \mathrm{TiO}_{2}, \mathrm{FeO}^{*}$, $\mathrm{MnO}, \mathrm{F}$ and Co tend all change and the variation curves of $\mathrm{CaO}, \mathrm{K}_{2} \mathrm{O}$ and $\mathrm{Rb}$ show apparent gaps, at around SI 40 . The cortlandtite and quartz hornblende gabbro are clearly poorer in $\mathrm{P}_{2} \mathrm{O}_{5}$ and $\mathrm{Sr}$ than the hornblende gabbro and quartz diorite.

A clinopyroxene analysis (NS3) lies on or near backward projected lines of the cortlandtite and quartz hornblende gabbro for almost all elements (Figs. 6a and 6b). Judging from these chemical variations and also from the abundance as a cumulus phase, clinopyroxene appears to be significant in 
the crystal fractionation process of the cortlandtite.

Cortlandtites are cumulates-enriched rocks, and therefore in no sense represent the composition of the original magma. The quartz hornblende gabbro, occurring as a fine-grained dike and being completely free from cumulus minerals, is regarded as a representative of liquid already differentiated to some extent. Therefore, it is assumed that SI of the parental magma of the cortlandtite and quartz hornblende gabbro was higher than 40 , indicating a picrite-basaltic magma in composition.

In Figs. 6a and 6b, the quartz diorite and granite relate to the hornblende gabbro by backward projections to a Ca-amphibole (NS12). The hornblende gabbros, containing abundant unzoned Ca-amphibole, are diopside-normative, whereas the quartz diorite and granite usually contain corundum in the norm. Therefore, the chemical variation patterns and the corundumnormative nature of the quartz diorite and granite are explained in terms of amphiboledominated fractionation (Ujike, 1975; Cawthorn and Brown, 1976; Cawthorn and O'Hara, 1976). The slight preponderance of the hornblende gabbro over the quartz diorite in volume may indicate that the parental magma of the hornblende gabbrogranite was a fairly $\mathrm{MgO}$-poor basaltic magma.

\section{Comagmatic or not comagmatic}

In Figs. $6 a$ and $6 b$, the compositions of the residual liquid that left after the formation of the cortlandtite may be plotted on or near the extension of straight lines, indicating the variation trend of cortlandtite and quart $z$ hornblende gabbro, calculated by the least squares method. If the horn- blende gabbro and quart $z$ diorite are formed immediately from the residual liquid, the straight lines of the two rocks cross the linear extension of the cortlandtite and quartz hornblende gabbro in all elements. However, such intersections are not detected in some elements, such as $\mathrm{TiO}_{2}, \mathrm{CaO}, \mathrm{K}_{2} \mathrm{O}$, $\mathrm{Rb}$ and $\mathrm{Sr}$ etc.

The quartz hornblende gabbros, being an evolved rock type of the clinopyroxenedominated fractionation course, have SI of 42 and 41. If the hornblende gabbro and quartz diorite are derived directly from the residual liquid of the clinopyroxene-dominated fractionation, some hornblende gabbros at least should have SI higher than the values for the formation of the quartz diorite. SI of all of the hornblende gabbros, however, are below 37, being clearly lower than those of the quartz hornblende gabbros.

The two facts mentioned above indicate that the residual liquid of the clinopyroxenedominated fractionation did not evolve immediately to the magmas of the hornblende gabbro and quartz diorite. Therefore, if all the various rock types are formed from a single magma, we can suppose another effective process. If fractional crystalllization gives significant effect, the subtracted material, as apparen in Figs. $6 \mathrm{a}$ and $6 \mathrm{~b}$, must be rich in $\mathrm{TiO}_{2}, \mathrm{~K}_{2} \mathrm{O}$ and $\mathrm{Rb}$, and poor in $\mathrm{CaO}$ and $\mathrm{Sr}$, and have SI higher than 42 . Only phlogopitic mica satisfies the restriction. However, no phlogopitic mica-rich igenous rocks are found in and around the cortlandtitic mass. Consequently, it seems likely that the Nishidohira mass was formed from two independent primary magmas.

Experimental works at $\mathrm{P}_{\mathrm{H}_{2} \mathrm{O}}=5 \mathrm{~kb}$ by Cawthorn et al. (1973) showed that the temperature range over which olivine and clinopyroxene are stable phases diminishes 
from MgO-rich basanitoid to basaltic andesite, and that amphibole appears at about $20^{\circ} \mathrm{C}$ below liquidus in basaltic andesite. Therefore, much opportunity for amphiboledominated fractionation may be expected in the more silica-saturated magma over the range from 2 to $10 \mathrm{~kb} \mathrm{P}_{\mathrm{H}_{2}} \mathrm{O}$ (Cawthorn and O'Hara, 1976). As mentioned before, the parental magma of the cortlandtite and quartz hornblende gabbro is inferred to be a picrite-basaltic magma in composition, whereas that of the hornblende gabbrogranite to be a fairly $\mathrm{MgO}$-poor basaltic magma.

The cortlandtite, quartz hornblende gabbro and hornblende gabbro have a common compositional feature, irrespective of the different rock group. They are rich in $\mathrm{K}_{2} \mathrm{O}$ and $\mathrm{Rb}$, and poor in Ni. Small cortlandtitic masses accompanied by abundant hornblende gabbros are sporadically distributed throughout the Abukuma Mountains. Some of the masses have been described (Fukasawa and Onuki, 1972; Kano et al., 1973; Tanaka, 1980), but $\mathrm{K}_{2} \mathrm{O}$-rich cortlandtite and/or gabbro, such rocks as the Nishidohira mass, have been never reported. Thus, the Nishidohira mass exhibits a peculiar feature in chemistry. This may indicate that the two parental magmas of the mass had originated from a common parental material enriched in $K$ and $R b$ and depleted in $\mathrm{Ni}$, such as mica-rich peridotite or amphibolite.

\section{Formation of the syenite and monzonite}

The syenite and monzonite, occurring as veins and patches only in the cortlandtite, are considered to be end products of the clinopyroxene-dominated fractionation and to be segregated when the almost congealed cortlandtite emplaced to the present position, as mentioned below.

The present bulk composition of poikilitic Ca-amphibole in the cortlandtite are not identical to the composition of liquid entrapped at the time of crystal accumulation. However, it can surely be assumed that the trapped liquid at the time of crystallization of the Ca-amphibole would be rich in $\mathrm{K}_{2} \mathrm{O}$ and $\mathrm{H}_{2} \mathrm{O}$, because greenish brown to brown Ca-amphiboles in the cortlandtite have high $\mathrm{K}_{2} \mathrm{O}$ content and high $\mathrm{K}_{2} \mathrm{O} / \mathrm{Na}_{2} \mathrm{O}$ ratio (Cawthorn et al., 1973; Helz, 1973; Ujike and Onuki, 1976; Yamamoto et al., 1977). It is expected that alkalis, especially $\mathrm{K}_{2} \mathrm{O}$, are enriched in the residual liquid during the clinopyroxenedominated fractionation, because cumulates consisting mainly of clinopyroxene are very poor in these elements. Precipitation of Ca-amphiboles from the residual liquid would have brought about further enrichment of alkalis and $\mathrm{H}_{2} \mathrm{O}$ in the latest liquid. The latest liquid would have been segregated to form the syenite and monzonite when the cortlandtite was intruded.

\section{Physico-chemical conditions during formation of the cortlandtite}

As shown in the route maps, only the cortlandtite crops out almost continuously, and the other rock types occur as dikes or patches in the cortlandtite. Therefore, it is apparent that the clinopyroxene-dominated and amphibole-dominated fractionations had occurred prior to the emplacement of the mass to the present position. Two magma chambers, in which the separation of crystalline phases and liquids was effectively operated, would have been located at deeper positions than the present levels.

When plagioclase is present, the $\mathrm{Ca}$ Tschermak's components $\left(\mathrm{CaAl}_{2} \mathrm{SiO}_{6}\right)$ in 
clinopyroxene solid solutions increase continuously with increasing pressures. The clinopyroxenes in the cortlandtite contain Ca-Tschermak's components up to 4.6 mole \%, that are apparently lower than those $(4.3-11.8$ mole $\%)$ in gabbroic inclusions derived from the lower crust (e.g. Yamazaki et al., 1966; Aoki, 1971; Shimazu et al., 1979). Aoki (1971) clarified that the gabbroic inclusions from Itinome-gata were formed at about $7-9 \mathrm{~kb}$. Therefore, the cortlandtites seem to be formed at pressures less than 7-9 kb. Under these pressures, olivine can coexist with plagioclase (Green and Hibberson, 1970).

From the abundance of Ca-amphibole and the widespread replacement of clinopyroxene by $\mathrm{Ca}$-amphibole, it is evident that the cortlandtite was formed under conditions of fairly high $\mathbf{P}_{\mathbf{B}_{2} \mathrm{O}}$, which increased with fractionation. In high $\mathrm{P}_{\mathrm{H}_{2} \mathrm{O}}$ experiments using natural basalts, amphibole crystallizes in advance of plaigoclase around $2-3 \mathrm{~kb}$ (Yoder and Tilley, 1962; Hollway and Burnham, 1972). Ca-amphibole crystallized earlier than plagioclase in the cortlandtite, impling its crystallization at $P_{\mathbf{H}_{2} \mathrm{O}} \geqq 2-3 \mathrm{~kb}$.

A K-Ar dating of quartz diorite (83 Ma) seems to indicate that the Nishidohira mass was intruded during the Late Mesozoic regional metamorphism. The Nishidohira metamorphic rocks were recrystallized at the higher temperature side near the triple point of $\mathrm{Al}_{2} \mathrm{SiO}_{5}$ polymorphs (Tagiri, 1971, 1973). From these information, the almost congealed cortlandtite is considered to have intruded at pressures about $5 \pm 2 \mathrm{~kb}$. The pressure estimate fluctuates according to the triple point experimentally or theoretically determined (e.g. Miyashiro, 1973).

Cortlandtites are expected to have recorded a wide range of equilibration tem- perature, since they show widespread textural evidence for postcumulus reaction.

Olivine-clinopyroxene geothermometer (Powell and Powell, 1974) gives temperatures around $1000^{\circ} \mathrm{C}$ for two pairs of olivine rim and primary clinopyroxene core.

Nominal equilibration temperatures of $830-880^{\circ} \mathrm{C}$ and $790-850^{\circ} \mathrm{C}$, are calculated for two primary pyroxenes pairs using the orthopyroxene-clinopyroxene geothermometers proposed by Wood and Banno (1973) and by Wells (1977), respectively.

The clinopyroxenes coexisting with orthopyroxene in the cortlandtites are characterized by high Wo content, plotting in the lower temperature field than $900^{\circ} \mathrm{C}$ in terms of the clinopyroxene-orthopyroxene solvus defined by Ross and Huebner (1975). Resorbed clinopyroxenes, poor in $\mathrm{Al}_{2} \mathrm{O}_{3}$ and $\mathrm{TiO}_{2}$, have generally though inconsistently higher Wo contents than primary clinopyroxenes (Fig. 4), indicating equilibration at still lower temperatures (Huebner, 1980).

Poikilitic Ca-amphiboles enclosing olivine, clinopyroxene and orthopyroxene would have crystallized at lower temperatures than equilibration temperatures of olivine-clinopyroxene pair and orthopyroxene-clinopyroxene pair. Ca-amphiboles experimentally formed at higher temperatures are strongly pleochroic (deep green to brown), becoming progressively browner, while those formed at least below $750^{\circ} \mathrm{C}$ are pale green to blue green and only faintly pleochroic (Helz, 1973). Pale green to colorless actinolitic amphiboles in the cortldantite might have formed at lower temperatures than $750^{\circ} \mathrm{C}$.

The considerably low equilibration temperatures of the cortlandtites, ranging from 1000 to less than $750^{\circ} \mathrm{C}$, may be attributed mainly to high $\mathrm{P}_{\mathbf{H}_{2} \mathrm{O}}$ and slow cooling of the 
mass. The mass is considered to have emplaced during the Late Mesozoic plutonism and regional metamorphism. In addition, the cortlandtite is intruded by some dikes that might have provided some heat. Since the surrounding rocks were still warm, the cortlandtite would have cooled slowly. The slower the cooling rate, the better the chance for the pyroxene and Ca-amphibole to approach low temperature equilibration (Huebner, 1980). Moreover, the condition of high $\mathrm{P}_{\mathrm{H}_{2} \mathrm{O}}$ and slow cooling the mass would have been suitable to form poikilitic Ca-amphibole of considerable size.

Acknowledgements: The authors wish to express their sincere thanks to Prof. Kenichiro Aoki and Dr. Hirokazu Fujimaki of Tohoku University, who kindly allowed the use of EMPA. Sincere appreciation is extended to Mr. Eizo Nakamura of Toronto University for carrying out a $\mathrm{K}$-Ar biotite dating. This study was supported in part by the Grand in Aid for Scientific Research from Ministry of Education, Japan.

\section{References}

Aoki, K. (1971), Petrology of mafic inclusions from Itinome-gata, Japan. Contrib. Mineral. Petrol., 30, 314-331.

Cawthorn, R.G., Curran, E.B. and Arculus, R.J. (1973), A petrogenetic model for the origin of the calc-alkaline suite of Grenada, Lesser Antilles. J. Petrol., 14, 327-337.

Cawthorn, R.G., and Brown, P. (1976), A model for the formation and crystallization of corundum-normative calc-alkaline magmas through amphibole fractionation. J. Geol., 84, 467-476.

Cawthorn, R.G., and O'Hara, M.J. (1976), Amphibole fractionation in calc-alkaline magma genesis. Am. J. Sci., 276, 309-329.

Fukasawa, T. and Onuki, H. (1972), On the gabbroic rocks in the northern Abukuma Mountains. J. Japan. Assoc. Min. Petr. Econ. Geol., 67, 1-10.*

Fujimaki, H. and Aoki, K. (1980), Quantitative microanalyses of silicates, oxides and sulfides using an energy-dispersive type electron probe. Sci. Rep. Tohoku Univ., Ser. III, 14, 261-268.

Goles, G.G. (1967), Trace elements in ultramafic rocks. In Ultramafic and related rocks (Wyllie, P.J. ed.), John Wiley and Sons, Inc., 352-362.

Green, D.H. and Hibberson, W. (1970), The instability of plagioclase in peridotite at high pressure. Lithos, 3, 209-221.

Hart, S.R., Brooks, C., Krogh, T.E., Davis, G.L. and Nava, D. (1970), Ancient and modern volcanic rocks: a trace element model. Earth Planet. Sci. Lett., 10, 17-28.

Helz, R.H. (1973), Phase relations of basalts in their melting range at $\mathrm{P}_{\mathrm{H}_{2} \mathrm{O}}=5 \mathrm{~kb}$ as a function of oxygen fugacity. J. Petrol., 14, 249-302.

Holloway, J.R. and Burnham, C.W. (1972), Melting relations of basalt with equilibrium water pressure less than total pressure. $J$. Pertol., 13, $1-29$.

Huebner, J.S. (1980), Pyroxene phase equilibria at low pressures. pp. 213-288 In Pyroxenes. (Prewitt, C.T. ed.), Mineral. Soc. America.

Irvine, T.N. and Baragar, W.R.A. (1971), A guide to the chemical classification of the common volcanic rocks. Can. J. Earth Sci., 8, 523548.

Kanisawa, S. (1979), Content and behaviour of flourine in granitic rocks, Kitakami Mountains, Northeast Japan. Chem. Geol., 24, 57-67.

Kano, H. and other (11 Persons). (1973), Geology of the Takanurki district, Scale 1:50,000. Geol. Surv. Japan.*

Kawano, Y. and Ueda, Y. (1965), K-Ar dating of the igneous rocks in Japan (III)-Granitic rocks in Abukuma massif. J. Japan. Assoc. Min. Petr. Econ. Geol., 54, 162-172.*

Koma, T. and Kurasawa, H. (1978), The chromium content of Cenozoic volcanic rocks-The western part of the San-in district in West Japan. J. Japan. Assoc. Min. Petr. Econ. Geol., 73, 39-46*

Kuno, H., Yamasaki, K., Iida, C. and Nagashima, K. (1957), Differentiation of Hawaiian magmas. Japan. J. Geol. Geor., 28, 179-218.

Miyashro, A. (1973), Metamorphism and metamorphic belts. George Allen and Unwin.

Onuki, H. (1968), Some rock-forming minerals of the cortlandtites from the Abukuma plateau. J. Japan. Assoc. Min. Petr. Econ. Geol., 59, 152-156.*

Poldervaart, A. and Hess, H.H. (1951), Pyroxenes in the crystallization of basaltic magma. f. Geol., 59, 472-489.

Powell, M. and Powell, R. (1974), An olivineclinopyroxene geothermometer. Contrib. Mineral. Petrol., 48, 249-263. 
Prinz, M. (1967), Geochemistry of basaltic rocks: Trace elements. In Basalts (Hess, $\mathrm{H}, \mathrm{H}$, and Poldervaart, A. eds.), vol. 1. John Wiley and Sons, Inc., 271-323.

Ross, M. and Huebner, J.S, (1975), A pyroxene geothermometer based on composition-temperature relationships of naturally occurring orthopyroxene, pigeonite and augite. Intern. Conf. Geothermometry Geobarometry (abst.), Pennsylvania State Univ., University Park, PA.

Shibata, K. (1968), K-Ar age determinations on granitic and metamorphic rocks in Japan. Rep. Geol. Surv. Japan. no. 227.

Shimaoka, H. and Watanabe, J. (1976), On the Nishidohira metamorphics of the Pre-Abean stage in Central Japan-1. Description and distribution of the lithofacies. J. Geol. Soc. Japan, 82, 531-542.*

Shimazu, M., Yano, T. and Tajima, M. (1979), Gabbroic inclusions in calc-alkali andesites of the Fossa Magna region, Central Japan. Sci. Rep. Nigata Univ., Ser. E. no. 5, 63-85.

Tagiri, M. (1971), Metamorphic rocks of the Hitachi district in the southern Abukuma plateau. J. Japan. Assoc. Min. Petr. Econ. Geol., 65, 77-103.

Tagiri, M. (1973), Metamorphism of Paleozoic rocks in the Hitachi district, southern Abukuma plateau, Japan. Sci. Rep. Tohoku Univ., Ser. $I I I, 12,1-67$.

Tanaka, H. (1980), Gabbroic rocks from the northern Abukuma Mountains, Northeast Japan. Bull. Yamagata Univ., Nat. Sci., 10, 127-142.

Terashima, S. (1971), Determination of cobalt, chromium, copper, lithium, nickel, lead strontium and zinc in silicates by atomic absorption spectrophotometry. Bull. Geol. Surv. Japan, 22, 245-259.*

Ueda, Y., Yamaoka, K., Onuki, H. and Tagiri, M. (1969a), K-Ar dating on the metamorphic rocks in Japan (II)-The Hitachi metamorphic rocks in southern Abukuma plateau. $J$. Japan. Assoc. Min. Petr. Econ. Geol., 61,
92-99.*

Ueda, Y, Aoki, K., Onuki, H. and Kato, Y. (1969b), Analytical data on the geochemical standard JB-1 basalt and $\mathrm{JG}-1$ granodiorite. $J$. Japan. Assoc. Min. Petr. Econ. Geol., 62, $35-39$ *

Ujike, O. (1975), Petrogenetic significance of normative corundum in calc-alkaline volcanic rock series. J. Japan. Assoc. Min. Petr. Econ. Geol, 70, 85-92.

Ujike, O. and Onuki, H. (1976), Phenocrystic hornblendes from Tertiary andesites and dacites, Kagawa Prefecture, Japan. J. Japan. Assoc. Min. Petr. Econ. Geol., 71, 389-399.

Watanabe, J. and Bikerman, M. (1971), K-Ar age of the Nishidohira gneiss complex in the Abukuma Mountains, Japan. Earth Sci. (Chikyu Kagaku), 25, 23-26.

Watanabe, M. (1921), Cortlandtite and its associated rocks from Nishidohira, Prov. Hitachi. Sci. Rep. Tohoku Univ., Ser. III, 1, 33-50.

Wells, P.R.A. (1977), Pyroxene thermometry in simple and complex system. Contrib. Mineral. Petrol., 62, 129-139.

Williams, G.H. (1886), The peridotites of the "Cortlandt Series" on the Hudson River near Peekskill, N.Y. Am. J. Sci., 3rd Ser., 31, 26-41.

Wood, B.J. and Banno, S. (1973), Garnet-orthopyroxene and orthopyroxene-clinopyroxene relationships in simple and complex systems. Contrib. Mineral. Petrol., 42, 109-124.

Yamamoto, M., Katsui, Y. and Niida, K. (1977), Petrology of volcanic rocks and ultramaficmafic inclusions of Oshima-Ōshima volcano. Bull. Volcanol. Soc. Japan, 22, 241-248.*

Yamazaki, T., Onuki, H. and Tiba, T. (1966), Significance of hornblende gabbroic inclusions in calc-alkali rocks. J. Japan. Assoc. Min. Petr. Econ. Geol., 55, 87-103.

Yoder, H.S., Jr., and Tilley, C.E. (1962), Origin of basalt magma: An experimental study of natural and synthetic rock system. J. Petrol., 3, 345-532.

- in Japanese with English abstract. 


\section{南部阿武隈山地，西堂平コートランド岩質岩体の岩石学}

\section{田中 久雄，蟹沢 聰史，大貫 化}

西堂平岩体は $83 \mathrm{Ma}$ の K-Ar 黒雲母年代を示し，単斜輝石を主体とした分別作用によりるたらされたコート ランド岩，石英角閃石ハンレイ岩，モンゾ岩，閃長岩と，角閃石を主体とした分別作用によりるたらされた角 䦍石ハンレイ岩, 石英閃緑岩, 花崗岩から主に構成される。てれらの岩石は同一のマグマからもたらされたので はなく，前者の初生マグマとしてはと゚クライト玄武岩質マグマが，後者にはやや $\mathrm{MgO}$ に乏しい玄武岩質マグマ が推定される。ただしいずれの岩石とも $\mathrm{K}_{2} \mathrm{O}$ と Rb にかなり富み， $\mathrm{Ni}$ に乏しいという共通した性質を有し， 2 つのマグマの起源物質は類似したものであったと思われる。2つの分別作用は $5 \pm 2 \mathrm{~kb}$ に位置していたと推定さ れる現在地に岩体が貫入する以前に行なわれた。現在地では単斜輝石を主体とした分別作用の最終残液がしばり 出されて，閃長岩とモンゾ岩が生成した。コートランド岩固結時の圧力は $7-9 \mathrm{~kb}$ 以下で $5 \pm 2 \mathrm{~kb}$ 以上，水蒸 気圧は 2-3 kb あるいはそれ以上であった。その平衡温度は $1000^{\circ} \mathrm{C} か ら 750^{\circ} \mathrm{C}$ 以下とかなり低温の幅広い温度 範囲を示す。岩体は中生代後期の広域変成作用時に貫入したために徐冷したと思われる。岩体の徐冷と高い水蒸 気圧のため、コートランド岩はかなり低温で平衡に達したものと推定される。 